\title{
Kernos
}

Revue internationale et pluridisciplinaire de religion grecque antique

$22 \mid 2009$

Varia

\section{Johannes Nollé, Kleinasiatische Losorakel. Astragal- und Alphabetchresmologien der hochkaiserzeitlichen Orakelrenaissance}

Fritz Graf

\section{(2) OpenEdition \\ 12 Journals}

\section{Electronic version}

URL: http://journals.openedition.org/kernos/1804

DOI: $10.4000 /$ kernos. 1804

ISSN: 2034-7871

\section{Publisher}

Centre international d'étude de la religion grecque antique

\section{Printed version}

Date of publication: 1 January 2009

Number of pages: 327-328

ISSN: 0776-3824

\section{Electronic reference}

Fritz Graf, « Johannes Nollé, Kleinasiatische Losorakel. Astragal- und Alphabetchresmologien der hochkaiserzeitlichen Orakelrenaissance », Kernos [Online], 22 | 2009, Online since 15 September 2011 connection on 21 September 2020. URL : http://journals.openedition.org/kernos/1804 ; DOI : https:// doi.org/10.4000/kernos.1804

This text was automatically generated on 21 September 2020 .

Kernos 


\title{
Johannes Nollé, Kleinasiatische Losorakel. Astragal- und Alphabetchresmologien der hochkaiserzeitlichen Orakelrenaissance
}

\author{
Fritz Graf
}

\section{REFERENCES}

Johannes NOLLÉ, Kleinasiatische Losorakel. Astragal- und Alphabetchresmologien der hochkaiserzeitlichen Orakelrenaissance, München, Verlag C.H. Beck, 2007. 1 vol. 21 苞 $30 \mathrm{~cm}, 331$ p., 24 pl. (Vestigia. Beiträge zur alten Geschichte, 57). ISBN : 978-3-406-56210-5.

1 This is the first comprehensive edition of a closed group of oracular inscriptions from Asia Minor that have been known, in isolated examples, for almost two centuries, but have been somewhat neglected by historians of religion and society in the Imperial Age; the only earlier collection, F. Heinevetter's slim Festschrift for the Archaeological Seminar of Breslau of 1912, presented only a fraction of the texts and does not lay claim to epigraphical expertise.

2 These inscriptions belong to a consistent geographical area in Southern Phrygia, Cilicia and Pisidia, date to second and third centuries of our era, and appear in two distinct forms, dice oracles and alphabet oracles. Both types are oracles with ready-made answers that the inquirer accessed by chance, either throwing dice (usually five, rarely seven) whose combination pointed to one specific answer, or using the alphabet in a way that eludes us to pick the correct answer from a list. Both methods thus called for a different number of ready-made answers, twenty-four for the alphabet oracles, fifty-six 
with five dice, 120 with seven. Alphabet oracles contained one verse per answer, usually in iambics, dice oracles several hexameters that did not only contain the answer but described also the exact nature of the throw; it mattered how different throws with the same sum were composed. It is these answers that are preserved on often impressive blocks of marble, either the short list of alphabetically ordered lines, or the very long list of numerically organized verse groups. Alphabet oracles were usually inscribed on stelai, slabs or the flat natural rock of a mountain side or a cave, oracles for five dice (the most common kind) were carved into the four sides of a large free-standing marble block that was almost two meters high; the even larger texts of the two (three?) oracles for seven dice, none of them fully preserved, seem to have been inscribed on the walls of public buildings.

$3 \quad \mathrm{~N}$ (ollé)s book starts with short introductory chapters (p. 1-17), on the history of research and the aim of this book, the use of dice or rather astragaloi, knuckle bones of sheep, and the tradition of dice oracles that is more wide spread in place and time than the preserved monuments let us suspect; Pausanias (VII, 25, 10), in the only literary record, describes an oracle for Heracles in Bura (Achaea), a few independent epigraphical fragments come from Thrace. The core of the book is a superb presentation of the epigraphical monuments from Anatolia, the 21 dice oracles (p. 19-221) and the 12 alphabet oracles (p. 223-279), in each case with all the necessary information on form, date, archaeological context, find history and bibliography, a critical Greek text with a German translation and a commentary; in some cases, the introductions contain brilliant vignettes on questions of Anatolian topography, society and religion, such as the detailed investigation into the find-spot of the alphabet oracle of Timbriada, the cave sanctuary of a local Meter (p. 265-268). In the case of the 18 oracles for five dice that all vary the same original text, $\mathrm{N}$. sensibly confines the presentation of the single texts to an introduction on the monument and a critical rendering of the Greek texts and reserves translation, commentary and structural analysis to go with the reconstructed Urtext (p. 123-181). The commentary is ample, very learned and often exhaustive (e.g. the splendid page on the scorpions that hide under stones, p. 164-165). Rarely things seem somewhat off the mark (e.g. p. 130 on

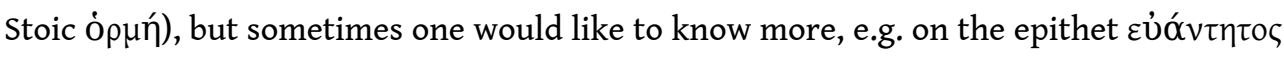
in Hierapolis (p. 258) that is most often applied to human interaction with a dangerous divinity (common in the Orphic Hymns; it would have been interesting to collect the parallels in the language of these texts and the vaguely contemporary Orphic Hymns; the few remarks on the style, p.186-188, deserve expansion), or on the verses that warn against forcing one's will upon a divinity (p. 142 - what ritual means are meant, and what is the underlying theology?). Each of the two main parts has a general introduction and a chapter that focuses on the common characteristics of the texts; a map (p. 23) and several charts help the reader with overview and comparison. A short final chapter, "Die südkleinasiatischen Losorakel und die religiös-mentalen Entwicklungen der Kaiserzeit," places them in their social context and in the wider world of divination, religion and society of the Antonine period (p. 281-293), with some emphasis on the Orakelrenaissance of the epoch, and some thoughts on the transition to Christianity after all; some of the oracles from these Anatolian stones are echoed in the Medieval Sortes Apostolorum(p. 293; see William E. Klingshirn, "Defining the Sortes Sanctorum. Gibbon, Du Cange, and Early Christian Lot Divination," Journal of Early Christian Studies 10 [2002], p. 77-130 and ID., "Christian Divination in Late Roman Gaul. The Sortes Sangallenses," in Sarah Iles Johnston and Peter Struck(eds.), Mantikê. Studies in 
Ancient Divination, Leiden, Brill, 2005, p. 99-128; both are absent from N., as is other nonepigraphical bibliography). Several indices (p. 305-331) conclude the book.

N. has given us a book that will establish itself as the most authoritative epigraphical treatment of the topic for some time to come: even when new texts will be found, as they presumably will, they will not drastically change the picture. Like Aude Busine in her recent Paroles d'Apollon (Leiden, Brill, 2005), and David Frankfurter in an important chapter of his Religion in Roman Egypt (Princeton University Press, 1998, p. 145-197), N. has remarkably expanded our knowledge of divination in the second and third centuries of the Imperial epoch and helped to lay the groundwork for more research that will help us to go beyond the descriptive Orakelrenaissance.

\section{AUTHORS}

FRITZ GRAF

Ohio State University 